Brit. J. industr. Med., 1962, 19, 19.

\title{
THE PHARMACOLOGICAL ACTIVITY OF EXTRACTS OF COTTON DUST
}

\author{
BY \\ ANNE DAVENPORT* ${ }^{*}$ and W. D. M. PATON $\dagger$ \\ From the Department of Pharmacology, Royal College of Surgeons of England
}

(RECEIVED FOR PUBLICATION APRIL 25, 1961)

\begin{abstract}
Aqueous extracts prepared from dust collected in the card-rooms of several cotton mills have been prepared and found to contain activity which contracts the smooth muscle of guinea-pig ileum, guinea-pig trachea, rat stomach strip, and rat duodenum. The extracts contained an unknown contractor substance which was dialysable, resistant to boiling for one hour, and not destroyed by the action of proteolytic enzymes. They also contained a small amount of 5-hydroxytryptamine. One of the dust samples also contained histamine, but it could not be detected in the other samples, one of which was known to possess bronchoconstrictor properties in man. The particulate material, even after repeated washing, was found to have some stimulant action on guinea-pig ileum.

There was no evidence for the release of histamine by the extracts in either cats or guinea-pigs, although a very small amount was released in rats. Jute dust is much less active than cotton dust, and the activity differs qualitatively. Cotton dust extracts were found to have pyrogenic activity but it is unlikely that pyrogens were responsible for the smooth-muscle contractor properties. Experiments with whole animals suggest that although smooth-muscle contracting substances were present in the extracts, it is possible that the symptoms of byssinosis are caused by the release of some other active bronchoconstrictor substance in the tissues. The mechanism of the release is not known; it may be caused by a soluble principle in the extract or due to the presence of particulate matter in the dust.
\end{abstract}

Recent epidemiological studies by Schilling (1956) have shown that byssinosis is still a very important problem amongst the Lancashire cotton workers. He suggested that the dust produced during the preparation of the fibres for spinning might contain a substance which exerts a specific effect on the pulmonary bronchioles. Earlier, Maitland, Heap, and Macdonald (1932) detected the presence of a histamine-like substance in extracts made from cardroom dust, and Macdonald and Prausnitz (1936) and Haworth and Macdonald (1937) later confirmed that there was a small amount of histamine together with an unknown substance present in cotton dust. Prausnitz (1936), however, suggested that the cause of byssinosis was probably not connected with the presence of histamine in cotton dust but was due to a soluble protein fraction which he had isolated; he and other workers obtained allergic

\footnotetext{
*In receipt of a grant from the Medical Research Council.
}

+Present address: Department of Pharmacology, Oxford. responses to this protein fraction and to extracts of cotton dust. The pattern of the disease, however, does not suggest that it is an allergy (Schilling, 1956). Respiratory function tests in cotton mills by McKerrow, McDermott, Gilson, and Schilling (1958) were compatible with the presence of a pharmacologically active agent in the dust and other experiments on respiration (Bouhuys, Lindell, and Lundin, 1960) also support this theory.

Before it is carded, the raw cotton passes through a number of cleaning processes which remove a large amount of plant debris and other "trash". In spite of dust suppression measures the card-room air still contains a considerable amount of dust and Roach and Schilling (1960) have shown that byssinosis is most prevalent amongst those who work near the carding engines. For this reason, dusts collected from the card-rooms of cotton mills have been used in this study in an attempt to identify the causative agent of the disease. Some of the results were demonstrated to the Physiological Society in April 1959. 


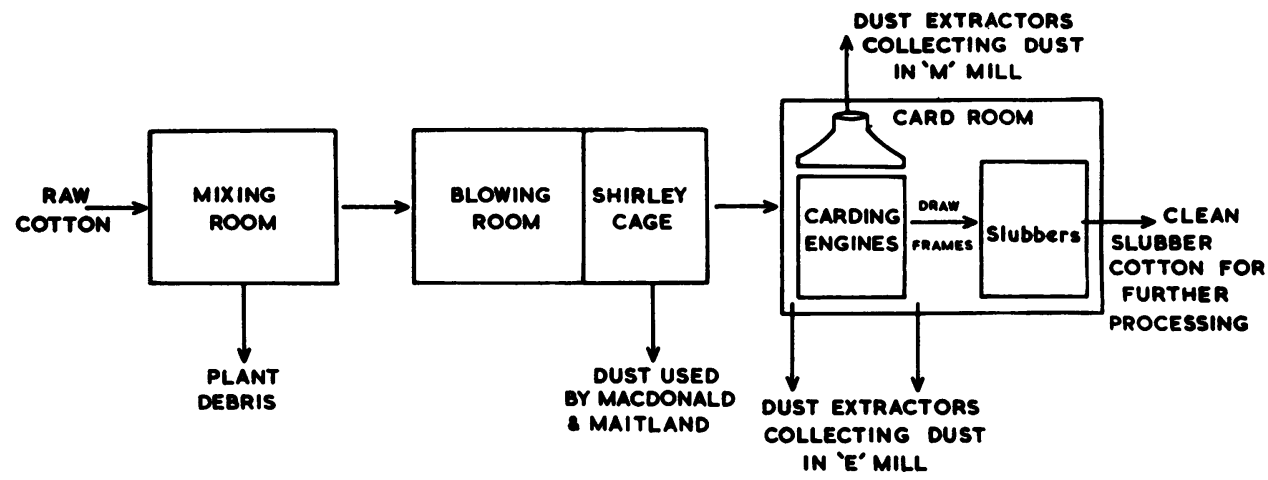

FIG. 1.-Diagram showing some of the stages in the processing of cotton and the sites where dust has been collected. These processes are all concerned with cleaning the cotton before spinning and are, therefore, the dustiest areas in the mill.

\section{MATERIAL AND METHODS}

\section{General Methods}

Source and Nature of Dusts.-The cotton dusts used have been obtained from two English cotton mills ( $E$ and M) both spinning coarse grades of cotton, from one Dutch cotton mill, and from one jute mill. An explanatory diagram of the relevant processes in an English cotton mill is seen in Fig. 1.

\section{English Cotton Dusts.}

M DUST.-The airborne dust used was collected by the card-room extraction plant from a close-fitting hood over the carding engines. In appearance it was like black-grey cotton wool with numerous fine black particles which flew out when the material was handled.

E DUST.-The airborne dust used was collected by the card-room extraction plant from the air in the card-room by suction through vents in the floor. It was similar to the $\mathbf{M}$ dust in appearance but not so dirty and with fewer particles.

Dutch Dust.- This was collected from the air in the card-room of a spinning mill from a horizontal surface above the carding engines. It consisted of creamywhite cotton fibres with plant debris and resembled more closely the material obtained from under the carding engines in $\mathbf{E}$ mill rather than the airborne dust mentioned above.

Slubber Cotton (E Mill).-This was cotton after it had been carded and slubbed and was therefore clean. It was creamy-white in appearance and there were no adhering particles.

Plant Debris (E Mill).-This was obtained in the mixing room from the opener which is a process prior to carding. It consisted almost entirely of dried pieces of plant, and there were only a very few cotton fibres.

Jute Dust.-The airborne dust used was collected by a dust extractor installed over the goods machines. This process, which splits the jute into fibres, produces a large quantity of dust and is carried out in the same room as both the carding and the spinning. In appearance the dust consisted of very coarse brown fibres with a few fine particles which looked like soil.

\section{Methods of Extraction: English Dusts}

(a) Distilled Water Extract.-20 g. dust was shaken for four hours with $400 \mathrm{ml}$. distilled water. The dust was sucked dry on a Buchner funnel without a filter paper to yield a slightly viscous extract full of black particles. After storing overnight at $-15^{\circ} \mathrm{C}$. it was separated by centrifugation at 5,000 r.p.m. (3,000 g.) for 20 minutes into a black-brown sticky deposit and a clear, slightly viscous, pale yellow supernatant; $1 \mathrm{ml}$. of this supernatant thus represented the soluble material in $50 \mathrm{mg}$. dust, and on freeze-drying, $5 \mathrm{mg}$. of powder was obtained per $\mathrm{ml}$. of supernatant. Approximately $10 \mathrm{mg}$. of deposit per $\mathrm{ml}$. of original extract was obtained by centrifugation, and on drying at $100^{\circ} \mathrm{C}$. this lost $70 \%$ of its weight. The residue $(3 \mathrm{mg}$.) consisted of about $40 \%(1.4 \mathrm{mg}$.) inorganic and $60 \%$ organic matter. Extracts of $E$ dust and $\mathbf{M}$ dust were prepared in this way.

Two extracts of jute dust were prepared in this manner, but the extracts were not viscous, were very pale yellow in colour, and most of the sediment separated on standing before centrifuging. In one extract, $1 \mathrm{ml}$. represented $50 \mathrm{mg}$. dust and, in the other, $1 \mathrm{ml}$. represented $130 \mathrm{mg}$. dust.

(b) Saline, Acid, and Alkaline Extracts.-E dust samples, cleaned slubber cotton, and the plant debris were also extracted with $0.9 \% \mathrm{NaCl}$ solution, $\mathrm{N} / 3$ $\mathrm{NaOH}$, and $\mathrm{N} / 3 \mathrm{HCl}$ using the same procedure as for distilled water extracts. Before biological testing the solutions were adjusted to neutrality. E dust and Dutch dust were also extracted by a method described by Dr. Bouhuys (personal communication): $3 \mathrm{~g}$. dust were ground with acid-washed sand in $20 \mathrm{ml}$. saline for about $30 \mathrm{~min}$., a further $30 \mathrm{ml}$. of saline was added, and the mixture stored at $+5^{\circ} \mathrm{C}$. overnight. Filtration through glass wool produced a cloudy brown extract. This could be separated into a clear pale yellow supernatant and a 
brown sediment by centrifugation; $1 \mathrm{ml}$. of this extract represented $60 \mathrm{mg}$. dust.

(c) Organic Solvents. -20 g. of $M$ dust was shaken for four hours with $400 \mathrm{ml}$. of choloroform: methanol $(2: 1)$. The mass was sucked dry on a Buchner funnel without a filter paper and the filtrate refiltered under suction through Whatman No. 540. The dust cake and the filter paper with its deposit were dried in vacuo; when all the organic solvent had been removed, the mass was shaken with distilled water as above giving a similar extract, $1 \mathrm{ml}$. of which again represented $50 \mathrm{mg}$. dust.

A glass column $(22 \times 4.5 \mathrm{~cm}$. $)$ was prepared with a rubber bung, glass tube, and screw clip at the bottom. On to this was poured a mixture of sand and glass wool and then a slurry of $50 \mathrm{~g}$. dust and $400 \mathrm{ml}$. acetone. The brown eluate was filtered through a Whatman No. 1 paper, as it was collected, and was stored at $-15^{\circ} \mathrm{C}$. Further washing of the cotton dust with acetone yielded first a pale yellow and then a colourless effluent. After centrifugation both supernatants were evaporated under reduced pressure in an atmosphere of nitrogen at room temperature; a sticky, oily residue remained. The residue was extracted first with $5 \mathrm{ml} .0 .9 \% \mathrm{NaCl}$ solution then with $5 \mathrm{ml}$. N/30 HCl; these were tested for pharmacological activity. The acetone extracted dust cake was removed from the column, dried, and extracted with distilled water as above.

\section{Chemical Methods}

Paper Chromatography.-Up to $1 \mathrm{ml}$. of solution was applied as a streak along one edge of sheets of Whatman No. 1 or 4 papers ( 8 in. $\times 8$ in.). These were developed by ascending chromatography in one dimension, using the butanol phase of a butanol : acetic acid : water $(4: 1: 5)$ solvent system. In some experiments a marker spot of a known substance was developed in parallel with the streak at one side of the paper.

5-Hydroxytryptamine was detected by dipping in Ehrlich's reagent (Rodnight, 1956). Peptides and similar compounds were detected by spraying with $0.4 \%$ ninhydrin in isopropyl alcohol, or by using the chlorinestarch-iodide method (Rydon and Smith, 1952).

Two methods of elution were used. In preliminary experiments the papers were cut serially into longitudinal strips $2 \mathrm{~cm}$. wide. The strips were shaken vigorously with a known volume of Tyrode solution and the extracts assayed. In later experiments when markers were used, the developed marker portion of the paper was cut off, the spot was stained, and then the strip with the corresponding $R_{F}$ value was cut out of the paper. These strips were eluted by dripping Tyrode solution down the paper, and the concentrated extract was collected in a graduated centrifuge tube.

Nitrogen Estimates.-The micro-Kjeldahl method was used.

Tonicity.-Tonicity was determined cryoscopically. The depression of freezing point was measured with a Beckman thermometer.

Potassium.-Potassium concentrations were determined on an Eel Flame Photometer.
Carbohydrates.-Reducing substances were determined by the arsenomolybdate method and total carbohydrates by the anthrone method (Ashwell, 1957). A Unicam SP 400 was used to measure optical density; for reducing sugars the colours were read at $510 \mathrm{~m} \mu$ and for total carbohydrates at $625 \mathrm{~m} \mu$.

Resins.-Four resins have been used in some preliminary studies to separate the active principle. The resins were:

Zeocarb 225 (sulphonic acid, 100-200 mesh, 2\% DVB) in $\mathrm{H}^{+}$form.

Zeocarb 226 (carboxylic acid type, 100-200 mesh) in $\mathrm{Na}^{+}$form at $p \mathrm{H} 7$.

Deacidite FF (quaternary ammonium type; 100-200 mesh; water regain 1.5 to 2 ) in $\mathrm{OH}^{+}$form.

Deacidite $G$ (amine type; $100-200$ mesh) in $\mathrm{Cl}^{-}$form at $p \mathrm{H} 7$.

The resins were regenerated with $\mathrm{HCl}$ and $\mathrm{NaOH}$ in the usual way and then varying amounts shaken with the cotton dust extract in graduated centrifuge tubes. After centrifuging, the supernatants were adjusted to neutrality when necessary and assayed for activity.

\section{Biological Methods}

Guinea-pig Ileum.-A terminal piece of ileum 4 to $6 \mathrm{~cm}$. long was mounted in an organ bath filled with $10 \mathrm{ml}$. Krebs solution at 35 to $36^{\circ} \mathrm{C}$. aerated with a mixture of $95 \% \mathrm{O}_{2} ; 5 \% \mathrm{CO}_{2}$. The Krebs solution contained the following constituents:- $\mathrm{NaCl} 6.9 \mathrm{~g} . / 1$.; $\mathrm{KCl} 0.35 \mathrm{~g} . / 1$; $\mathrm{CaCl}_{2} \cdot 6 \mathrm{H}_{2} \mathrm{O} 0.55$ g./l.; $\mathrm{KH}_{2} \mathrm{PO}_{4} 0 \cdot 16$ g./l.; $\mathrm{MgSO}_{4} \cdot 7 \mathrm{H}_{2} \mathrm{O}$ 0.29 g./l.; glucose 1.0 g./l.; $\mathrm{NaHCO}_{3} 2.1$ g. $/ 1$.

Guinea-pig Trachea.-This was prepared as illustrated in Fig. 2, making use of the band of circular muscle running down the dorsal side of the trachea. The tissue was mounted in a 5 or $10 \mathrm{ml}$. organ bath filled with Krebs solution at $37^{\circ} \mathrm{C}$, and aerated with $95 \% \mathrm{O}_{2}$; $5 \% \mathrm{CO}_{2}$.

Rat Stomach Strip.-The method of Vane (1957) was used, with Tyrode as a bathing fluid but without hyoscine.

Rat Duodenum.- - The preparation developed by Horton (1959) was used, bathed with de Jalon's fluid, both with and without atropine.

Histamine Release.-This was investigated by two methods, one by giving intraperitoneal injections to rats (Fawcett, 1954), and the other using the perfused cat skin preparation (Feldberg and Paton, 1951).

Drugs.-The following drugs were used: histamine acid phosphate; mepyramine maleate; acetylcholine chloride; hyoscine hydrobromide; 5-hydroxytryptamine creatinine sulphate; brom-lysergic acid diethylamide (BOL 148); hexamethonium bromide; dihydroergotamine methanesulphonate.

All drug doses are given in terms of the salt except histamine and 5-hydroxytryptamine which are given in terms of the base. 


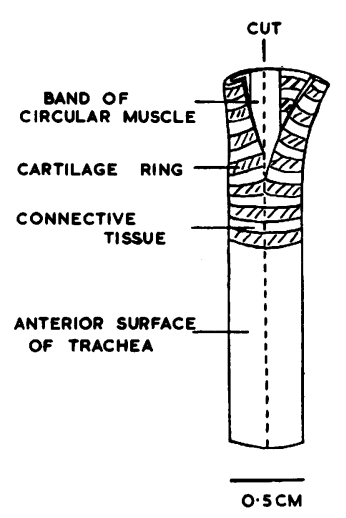

FIG. 2a

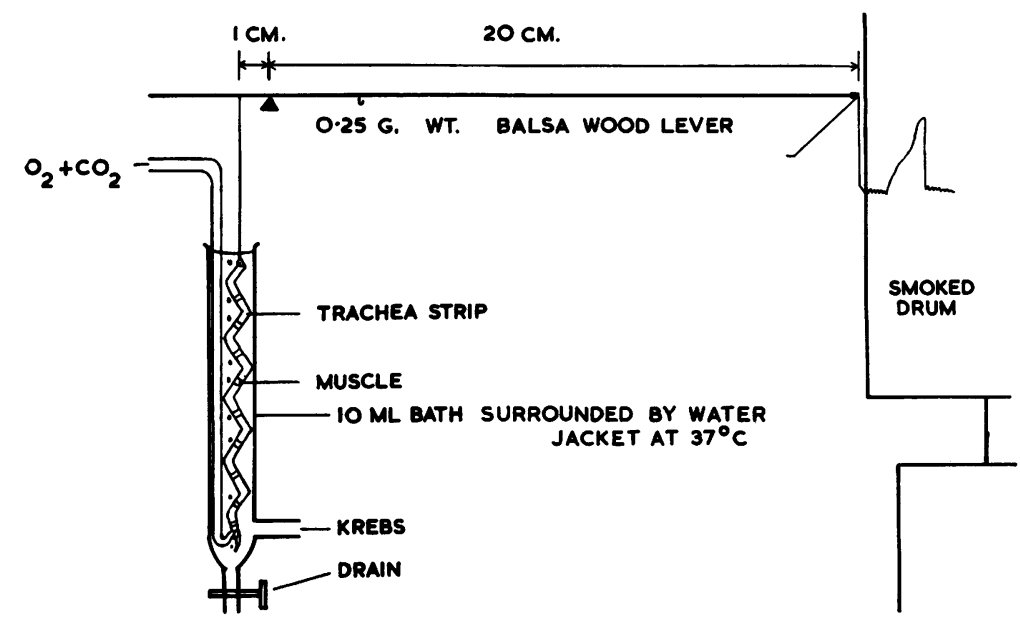

FIG. 2c

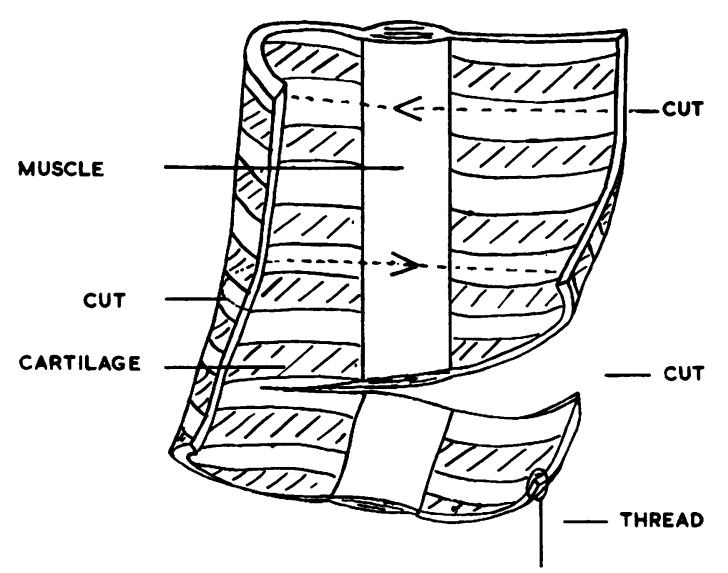

$1 \mathrm{CM}$

FIG. 2b

Enzyme Preparations.-Crystalline salt-free trypsin (2,640 units/mg.) and chymotrypsin (975 units/mg.) (Armour). Papain, commercial preparation (B.D.H.). The bradykinin preparation was kindly supplied by Dr. E. W. Horton; $1 \mathrm{mg}$. of this preparation was equivalent to $2 \mu \mathrm{g}$. pure bradykinin.

Pyrogens.-These were kindly supplied by Dr. T. D. Whittet.

\section{RESULTS}

Smooth muscle contractor activity was present in the distilled water extracts with all smooth muscles tested. Fig. 3 illustrates the contractions of guinea-pig ileum, guinea-pig trachea, and rat stomach, produced by cotton dust extract; and activity on the rat duodenum is shown in Fig. 10. The activity in cotton dust extracts was greater than, and qualitatively different from, that in the jute dust extracts; the latter never showed the rapid peak that was seen with the cotton dust extracts. Jute dust extract caused a very slow contraction in some preparations of guinea-pig ileum when high doses of dust equivalents were given; on the rat stomach preparation it exhibited tachyphylaxis (Fig. 4). The contractor activity in the cotton dust was extracted equally well by saline and distilled water, but no activity was extracted by $\mathrm{N} / 3 \mathrm{HCl}$ or $\mathrm{N} / 3 \mathrm{NaOH}$. However, both saline, distilled water, 
FIG. 3.-Guinea-pig ileum, guinea-pig trachea, and rat stomach strip showing contractions to cotton dust extract, histamine (HIST), acetylcholine $(\mathrm{ACH})$, and 5-hydroxytryptamine (5-HT). Capacity of isolated organ bath was $10 \mathrm{ml}$. for guineapig ileum and trachea and $5 \mathrm{ml}$. for rat stomach strip. All doses given at white dots and washed out by overflow after 30 seconds on guineapig ileum, five minutes on guineapig trachea, and 90 seconds on rat stomach strip.

Cotton dust doses were all given in an aqueous or saline solution, but are shown in terms of $\mathrm{mg}$. dust for comparison.

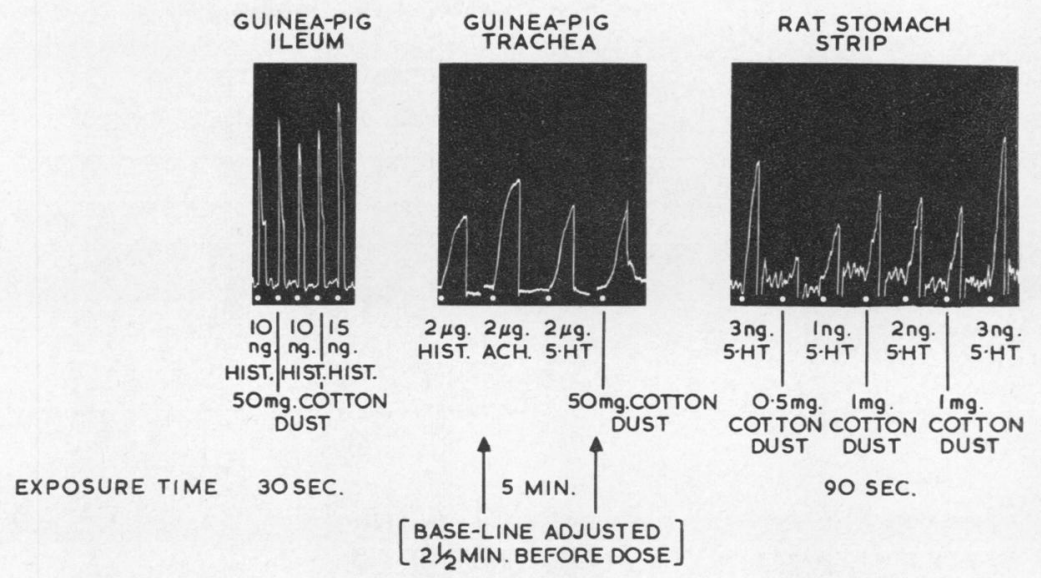

and $\mathrm{N} / 3 \mathrm{HCl}$ extracted some activity from the plant debris. Acetone and chloroform:methanol extracted a trace of rat stomach contractor substance but none of the guinea-pig ileum or trachea activity.

\section{Chemical Tests}

Chemical and Physical Properties of Extracts. The activity was dialysable and resistant to heating at $100^{\circ} \mathrm{C}$. for one hour, was stable to autoclaving at $15 \mathrm{lb} . / \mathrm{sq}$. in. for 30 minutes, and could be stored for several months at $-15^{\circ} \mathrm{C}$. without loss of activity. The activity on the guineapig ileum and the rat stomach was resistant to freeze-drying, but the guinea-pig trachea activity was always less and was sometimes completely abolished. The guinea-pig ileum contractor activity was also stable to concentration under reduced atmospheric pressure.

Chemical Constitution.--Cotton dust extracts contained a fairly high potassium level $(0.4$ to $0.6 \mathrm{mg} . / \mathrm{ml}$.) and a low sodium level $(0.05 \mathrm{mg} . / \mathrm{ml}$.), and had $p \mathrm{H}$ levels varying from 6 to 7 . Tonicity measurements showed that the extract was also rather hypotonic, the osmolarity being about $80 \mathrm{mosm} / \mathrm{l}$. compared with that of isotonic saline which is $\mathbf{3 1 0}$ mosm/l. (Table 1). As all or any of these properties might have been the cause of the contractor activity in the extracts, they had to be tested and the results are illustrated in Fig. 5. From these records and others on the guineapig trachea (which are not illustrated) it was clear that none of these factors was responsible for the contractor activity. The methods for reducing substances and total carbohydrate were not very specific, but the levels of these constituents and also those of the potassium and soluble nitrogen probably reflected the amount of plant material, other than cotton fibres, present in the dusts. The results also showed that all these constituents were considerably higher in the cotton than in the jute dusts, suggesting that the latter contain less plant debris. It is this fraction of the dust which has been previously suggested

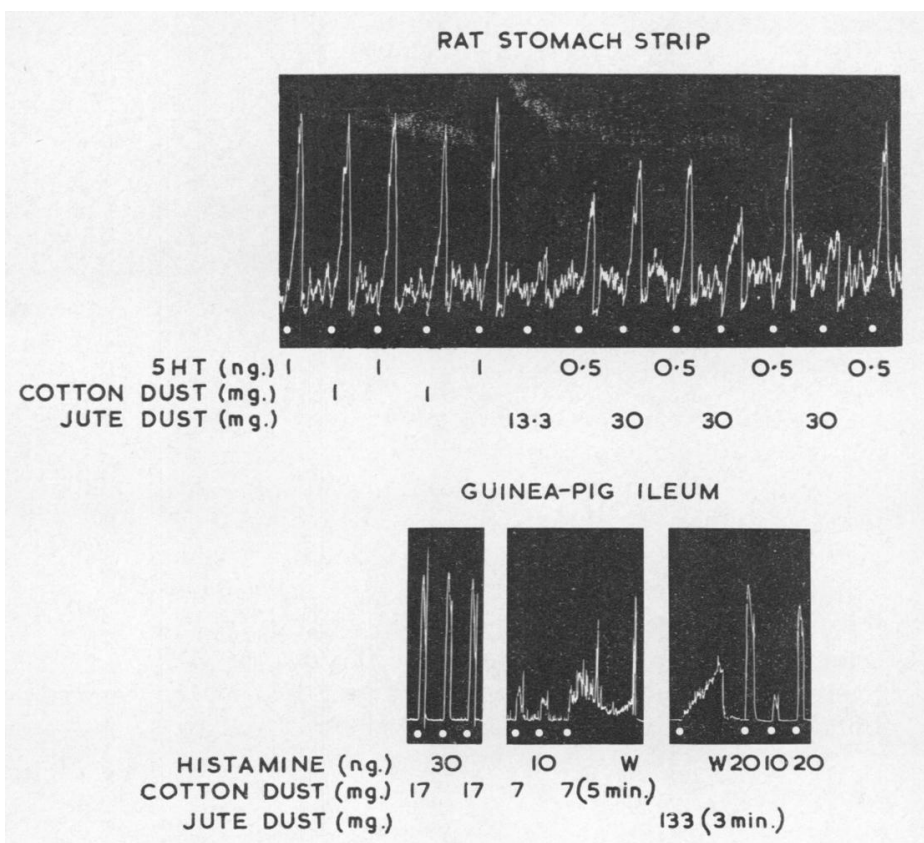

FIG. 4.-Guinea-pig ileum and rat stomach strip. Activity in cotton dust compared with that in jute dust. The rat stomach strip exhibited tachyphylaxis after several doses of jute dust extract. 
TABLE 1

CHEMICAL CONSTITUTION

(All values estimated in distilled water extract and expressed per g. dust)

\begin{tabular}{|c|c|c|c|c|c|}
\hline & \multicolumn{5}{|c|}{ Dust } \\
\hline & $\mathbf{M}$ & $\mathbf{E}$ & Dutch & Jute & Plant \\
\hline $\begin{array}{l}\text { Total nitrogen (mg.) } \\
\text { Reducing substances (mg.) } \\
\text { Total carbohydrate (mg.) } \\
\text { Potassium (mg.) } \\
\text { Tonicity of extract } \\
\text { pH of extract } \\
\text { Sodium (mg.) }\end{array}$ & $\begin{array}{c}3.8 \\
21 \\
42 \\
11 \cdot 6 \\
80 \mathrm{mosm} / 1 \\
6.3 \\
0.05\end{array}$ & $\begin{array}{c}3.4 \\
8.6 \\
16 \\
7.6 \\
6.7\end{array}$ & $\begin{array}{r}1.7 \\
10 \cdot 6 \\
6.5\end{array}$ & $\begin{array}{l}0.6 \\
2.9 \\
6.0 \\
0.9 \\
6.5\end{array}$ & $\begin{array}{r}14 \cdot 7 \\
6.6\end{array}$ \\
\hline
\end{tabular}

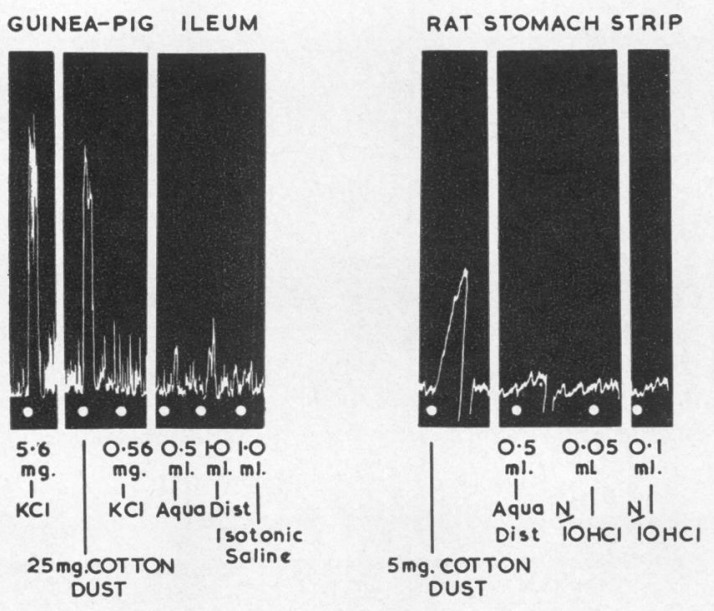

Fig. 5.-Guinea-pig ileum and rat stomach strip. Contractions to cotton dust extract, isotonic $\mathbf{K C l}$ solutions of same $\mathrm{K}^{+}$concentration as in extract ( $0.56 \mathrm{mg}$.), and 10 times stronger $(5.6 \mathrm{mg}$.); distilled water; and hydrochloric acid of a far lower $p \mathrm{H}$ than in dust extract.

(Roach and Schilling, 1960) as the source of the material causing byssinosis.

Chemical Reactions.-The guinea-pig trachea and guinea-pig ileum activities were insoluble in methanol, chloroform, acetone, ethanol, or petroleum ether $\left(\mathrm{Bp}, 40^{\circ}\right.$ to $60^{\circ} \mathrm{C}$.). On precipitation with $90 \%$ acetone, the rat duodenum activity was found to be equally divided between the precipitate and the supernatant; the supernatant activity being antagonized by brom-lysergic acid. The guinea-pig ileum activity was stable to $\mathrm{N} \mathrm{HCl}$ and $\mathrm{N} \mathrm{NaOH}$ for 30 minutes, but some activity was destroyed by $\mathrm{N} / 10 \mathrm{HCl}$ and $\mathrm{N} / 10 \mathrm{NaOH}$ after one hour at room temperature.

The distilled water extracts of cotton dust gave a strongly positive reaction with ammoniacal $\mathrm{AgNO}_{3}$ and a rather weak reaction with $0.4 \%$ ninhydrin in isopropyl alcohol. The chlorine-starch-iodine reaction (Rydon and Smith, 1952) produced a pale grey colour (with $0.5 \mathrm{mg}$. freeze-dried powder) and, after chromatography with higher concentrations of the extract, a blue-black coloured comet-shaped streak was detected on the paper. The colours were compared with those produced by dilute solutions of egg albumen and the amino-acid valine; albumen $(0.1 \mathrm{mg}$.) produced a dark purple colour while there was no reaction with valine $(0.1 \mathrm{mg}$.). Other simple tests with indicators suggested that the cotton dust extracts had only slight buffering power which compared with that of albumen or valine.

In studies with ion-exchange resins (Table 2) it was found that the activity was largely $(70 \%)$ removed by Zeocarb 225 (strong acid) and partly $(40 \%)$ removed by Zeocarb 226 (weak acid). About $30 \%$ of the activity was removed by Deacidite FF (strong base), but none was taken up by Deacidite $G$ (weak base). Shaking with saline, $\mathrm{N} / 10 \mathrm{NaOH}$ or $\mathrm{N} / 10 \mathrm{HCl}$, did not elute any activity from Zeocarb 225 and 226, but $\mathrm{N} \mathrm{NaOH}$ eluted a little. The pale yellow colour of the extracts was adsorbed by the basic resins, Deacidite FF and Deacidite G, but not by the acidic resins. These results therefore suggested that the contractor substance had both basic and acidic groups in a ratio of about 2 basic : 1 acidic. The chemical and physical properties indicated the presence of several substances, and that the activity might be associated with the peptide-like properties exhibited by the extracts.

TABLE 2

RESIN EXPERIMENTS

\begin{tabular}{c|c|c}
\hline \multicolumn{1}{c|}{ Resin } & $\begin{array}{c}\text { Moist } \\
\text { Ratio, Resin : Dust Extract }\end{array}$ & $\begin{array}{c}\text { Percentage of Activity } \\
\text { Removed by Resin }\end{array}$ \\
\hline Zeocarb 225 & $1: 4$ & 70 \\
Zeocarb 226 & $1: 4$ & 70 \\
Deacidite FF & $1: 4$ & 10 \\
Deacidite G & $1: 1$ & 40 \\
& $1: 4$ & 20 \\
& $1: 1$ & 30 to 40 \\
& $1: 4$ & Nil \\
\hline
\end{tabular}


Fig. 6.-Rat stomach strip. Contractions to cotton dust extract compared with those to 5-hydroxytryptamine (5-HT) and acetylcholine and the effects of brom-lysergic acid diethylamide (Brom LSD) $10^{-7}$ on their contractions. $\mathrm{ACH}$ is seen to be virtually unaffected and, while cotton dust extract and 5-HT are both reduced, the former is affected very much less.
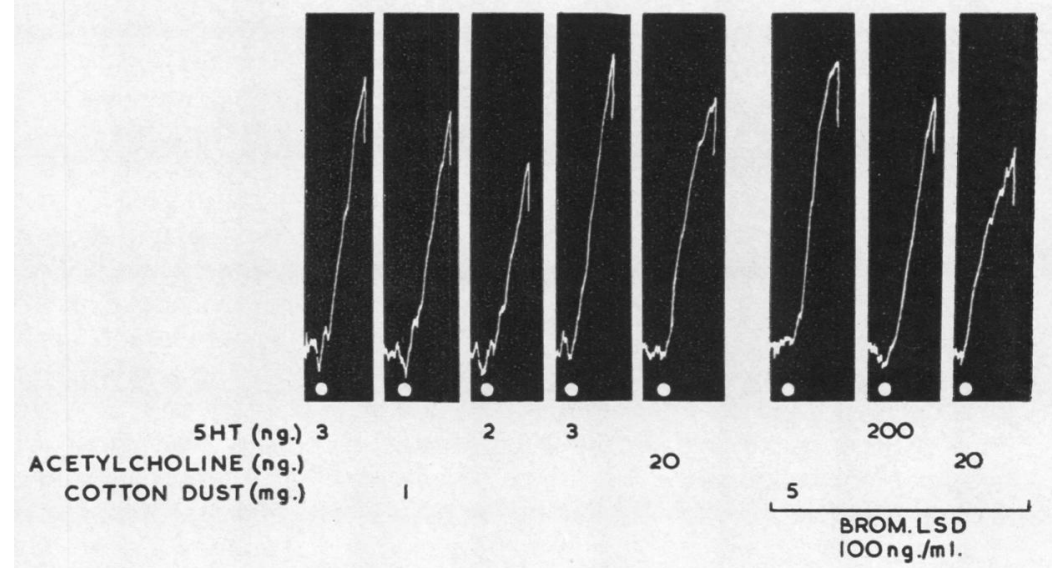

\section{Pharmacological Tests}

After a few experiments it became obvious that several biologically active substances were present in the extracts; they were therefore tested to find whether the activity was due to known contractor substances, such as histamine, acetylcholine or 5hydroxytryptamine.

When tested on the rat fundus preparation the contraction brought about by the cotton dust extracts was shown to be partly due to the presence of 5-hydroxytryptamine. This tissue is very sensitive to 5-hydroxytryptamine, and it was found that it was also sensitive to as little as $0.5 \mathrm{mg}$. dust equivalent. Brom-lysergic acid (BOL 148), which is a specific antagonist for 5-hydroxytryptamine, had considerable effect on the activity of the cotton dust extract but it was always less than its effect on 5-hydroxytryptamine (suggesting the presence of some other stimulant) (Fig. 6). Further evidence for the presence of 5-hydroxytryptamine in the extracts was obtained by paper chromatography. Chromatograms of 5-hydroxytryptamine were first run and checked to prove that this was a satisfactory method for separating small amounts of 5-hydroxytryptamine that could not be detected chemically. The 5-hydroxytryptamine had an $\mathbf{R}_{\mathbf{F}}$ equal to 0.45 to 0.47 and on elution all the activity was recovered from this area of the paper. In the chromatograms of the cotton dust extract, activity eluted from the $R_{F} 0.45$ to 0.47 area contained the bulk of the activity; it was antagonized by bromlysergic acid to exactly the same degree as 5-hydroxytryptamine. A small amount of activity remained at the origin and this was only very slightly affected by the antagonist. These results are illustrated in Fig. 7.

It was concluded from these experiments that about $1 \mu \mathrm{g}$. 5-hydroxytryptamine/g. dust was present in the cotton dust extracts. However, it was obvious that at least one other contractor substance was present and this was further supported by results from experiments on the guinea-pig trachea and the rat duodenum. These two tissues are not so sensitive to 5-hydroxytryptamine as the rat fundus, and a dose of $0.5 \mathrm{ml}$. of cotton dust extract which would contract the guinea-pig trachea contained insufficient 5-hydroxytryptamine ( $25 \mathrm{ng}$.) to account for this effect. Furthermore, the contractor activity of the
FIG. 7.-Rat stomach strip. Contractions to 5-hydroxytryptamine (5-HT), the eluate from the origin of the chromatogram of cotton dust extract, and the eluate from the area with an $R_{F}$ value of 0.45 to 0.47 corresponding to the $R_{F}$ of a marker spot of 5-HT. Brom LSD $10^{-7}$ is shown to reduce the 5-HT and $R_{F} 0.45$ to 0.47 eluate to the same extent while having little effect on the eluate from the chromatogram origin.
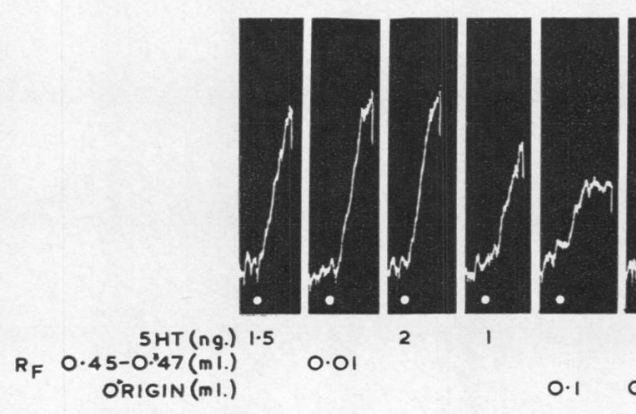

$0.1 \quad 0.2$
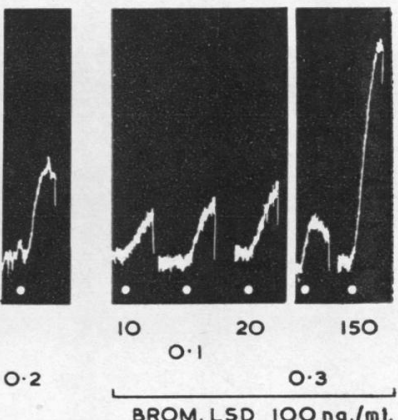
cotton dust extracts was not susceptible to bromlysergic acid on the guinea-pig trachea or the rat duodenum, and the extracts continued to contract the rat duodenum in the presence of a high concentration $\left(10^{-6}\right)$ of 5 -HT.

As earlier workers (Maitland et al., 1932; Haworth and Macdonald, 1937) had found that there was frequently a small amount of histamine in cotton dust, it was thought that the contractor activity might be due to the presence of this substance. However, guinea-pig ileum and guinea-pig trachea experiments showed that the contractor activity in these cotton dust extracts was not due to histamine. The histamine equivalents on these two tissues were quite different (Table 3 ) and the activity was not antagonized by the anti-histamine, mepyramine maleate (Fig. 8). The contraction produced by the Dutch cotton dust extract was also insensitive to mepyramine.

English cotton dust was found to vary, however, in its histamine content as had been suggested by the earlier workers, and one of the samples collected from mill $\mathrm{M}$ at a later date was found to contain histamine together with the unknown contractor. In a guinea-pig ileum experiment, mepyramine maleate $10^{-7}$ reduced the histamine responses fiftyfold and the response to this $M$ dust extract sevenfold, while responses to acetylcholine and two other extracts (prepared from E dust) were unchanged. Therefore, this sample of $M$ dust contained histamine as well as the unknown substance, but the other two dusts contained only the latter.
One of these $E$ dust samples was collected by a Hexhlet dust extractor in E mill during the course of some experiments on respiratory function (McKerrow et al., 1958). In these experiments, subjects were breathing dusty card-room air, and falls in M.B.C. (maximum breathing capacity) were recorded, indicating that this sample of dust had bronchoconstrictor activity in spite of the absence of detectable histamine. The activity in the distilled water extracts of the plant debris was similar to that in the cotton dust extracts and was mepyramine insensitive, but the activity extracted by $\mathrm{N} / 3 \mathrm{HCl}$ was reduced by mepyramine to the same extent as histamine. These results tend to confirm the theory that the plant matter was the source of both the unknown contractor and the histamine.

The contractor activity in cotton dust extracts was not antagonized by hyoscine hydrobromide when tested on the guinea-pig ileum and the guineapig trachea (Fig. 9). This figure shows that the acetylcholine activity was considerably reduced and although the responses to the cotton dust extracts were slightly reduced, the histamine equivalents were unchanged by the hyoscine. The activity of cotton dust extracts on the guinea-pig trachea was also unaffected by hexamethonium bromide. These results showed that the activity was not due to the stimulation of ganglia, nor to the presence of acetylcholine (or a similar substance). Dihydroergotamine was also without effect on the response.

As the cotton dust activity did not appear to be entirely due to any of the known pharmacological

TABLE 3

ACTIVITY EQUIVALENTS EXPRESSED AS $\mu \mathrm{g}$. PER g. DUST

\begin{tabular}{|c|c|c|c|c|c|c|c|c|}
\hline & & \multicolumn{4}{|c|}{ English Dusts } & \multirow{3}{*}{$\begin{array}{l}\text { Dutch } \\
\text { Dust }\end{array}$} & \multirow{3}{*}{$\begin{array}{r}\text { Jute } \\
\text { Dust }\end{array}$} & \multirow{3}{*}{$\begin{array}{l}\text { "Plant } \\
\text { Debris" } \\
\text { from } \\
\text { Blowing } \\
\text { Room }\end{array}$} \\
\hline & & \multicolumn{2}{|c|}{ M Dust } & \multicolumn{2}{|c|}{ E Dust } & & & \\
\hline & & $\begin{array}{c}\text { Distilled } \\
\text { Water } \\
\text { Extract }\end{array}$ & $\begin{array}{l}\text { Organic } \\
\text { Solvent } \\
\text { Then } \\
\text { Aqua Dist. }\end{array}$ & $\begin{array}{c}\text { Distilled } \\
\text { Water } \\
\text { Extract }\end{array}$ & $\begin{array}{l}\text { Saline } \\
\text { Extract } \\
\text { Prepared } \\
\text { By Dutch } \\
\text { Method }\end{array}$ & & & \\
\hline $\begin{array}{c}\text { Guinea-pig } \\
\text { trachea }\end{array}$ & $\left\{\begin{array}{l}\text { Histamine } \\
\text { Acetylcholine } \\
\text { 5-Hydroxytryptamine }\end{array}\right.$ & $\begin{array}{c}20-70 \\
(\operatorname{mean}=36) \\
15-70 \\
(\text { mean }=35) \\
4-70 \\
(\text { mean }=38)\end{array}$ & $\begin{array}{c}20-100 \\
(\text { mean }=58) \\
10-15 \\
(\text { mean }=13)\end{array}$ & 10 & & & $2 \cdot 3$ & \\
\hline $\begin{array}{l}\text { Guinea-pig } \\
\text { ileum }\end{array}$ & $\left\{\begin{array}{l}\text { Histamine } \\
\text { Acetylcholine } \\
\text { 5-Hydroxytryptamine }\end{array}\right.$ & $\begin{array}{c}0 \cdot 3-4 \\
(\operatorname{mean}=1 \cdot 1) \\
0.83\end{array}$ & $\begin{array}{c}1 \cdot 1-2 \cdot 8 \\
(\text { mean }=1 \cdot 9) \\
0 \cdot 5 \cdot 2 \cdot 1 \\
4.9 \\
\end{array}$ & $\begin{array}{c}0.3-0.8 \\
(\underset{0.4}{\operatorname{mean}}=0.5)\end{array}$ & $\underset{0.4}{0.5-2 \cdot 0}$ & $\begin{array}{c}0 \cdot 8-5 \cdot 0 \\
(\underset{0.62}{\operatorname{mean}}=2 \cdot 6) \\
0.62\end{array}$ & $\begin{array}{c}0-0.11 \\
(\text { mean }=0.06) \\
0.07\end{array}$ & $\begin{array}{c}0 \cdot 25-1 \cdot 2 \\
(\operatorname{mean}=0 \cdot 64)\end{array}$ \\
\hline Rat stomach & $\left\{\begin{array}{l}\text { Acetylcholine } \\
\text { After BOL 10-- } \\
\text { 5-Hydroxytryptamine }\end{array}\right.$ & $\begin{array}{c}20 \\
4 \\
1-4 \\
(\text { mean }=2 \cdot 5) \\
\end{array}$ & $\begin{array}{c}2-4 \cdot 2 \\
(\text { mean }=2 \cdot 6)\end{array}$ & 0.5 & & & $\mid \begin{array}{c}0.12 \\
\text { tachyphylaxis }\end{array}$ & $0 \cdot 38$ \\
\hline Rat duodenum & $\left\{\begin{array}{l}\text { Acetylcholine } \\
\text { 5-Hydroxytryptamine }\end{array}\right.$ & $\begin{array}{c}4-7 \\
\left(\text { mean }_{2-5}=5\right) \\
(\text { mean }=3.5)\end{array}$ & & $1 \cdot 3$ & & & $0 \cdot 3$ & \\
\hline
\end{tabular}


GUINEA-PIG ILEUM
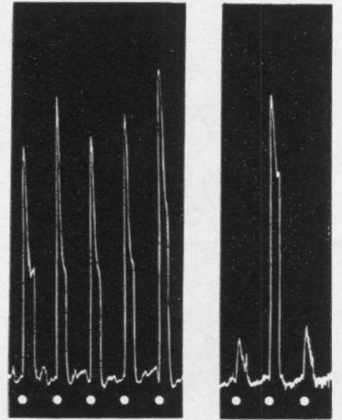

10ng. IOng. I5ng. 60ng. 60 ng. HIST. HIST. HIST. HIST. HIST. 50mg.COTTON
DUST

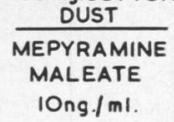

FiG. 8.-(a) Guinea-pig ileum and guineapig trachea, and $(b)$ guinea-pig ileum. Contractions due to cotton dust extract compared with those due to histamine (HIST), acetylcholine, and 5-hydroxytryptamine (5 - HT)

Mepyramine maleate given at the

levels shown which were sufficient to reduce the histamine response, but not that to any of the other agonists.

FIG, 9,-Guinea-pig ileum. Contractor activity of cotton dust extracts compared with that of histamine and acetylcholine. Hyoscine hydrobromide (Hyos) 10-8 reduced the acetylcholine considerably, but cotton dust extract is still equivalent to the same amount of histamine.
GUINEA-PIG TRACHEA
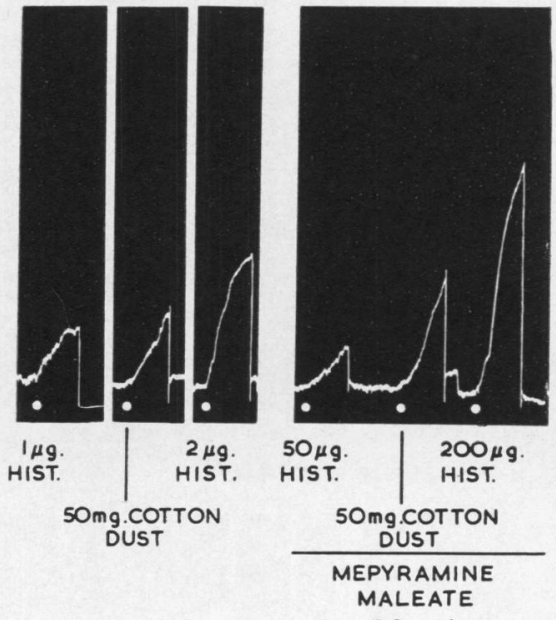

FIG. $8 \mathrm{a}$

IOOก

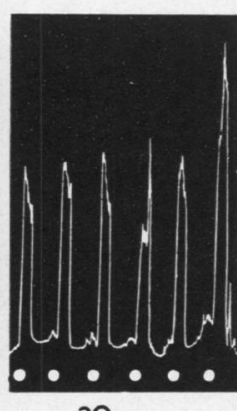

10

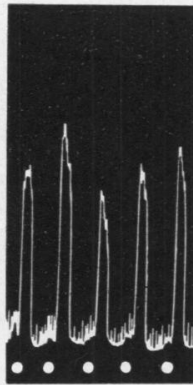

HISTAMINE (ng.) 20 5 HT (ng.) COTTON DUST (mg.) 14

14

14
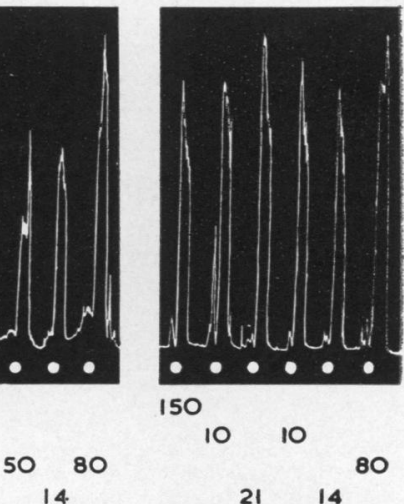

10
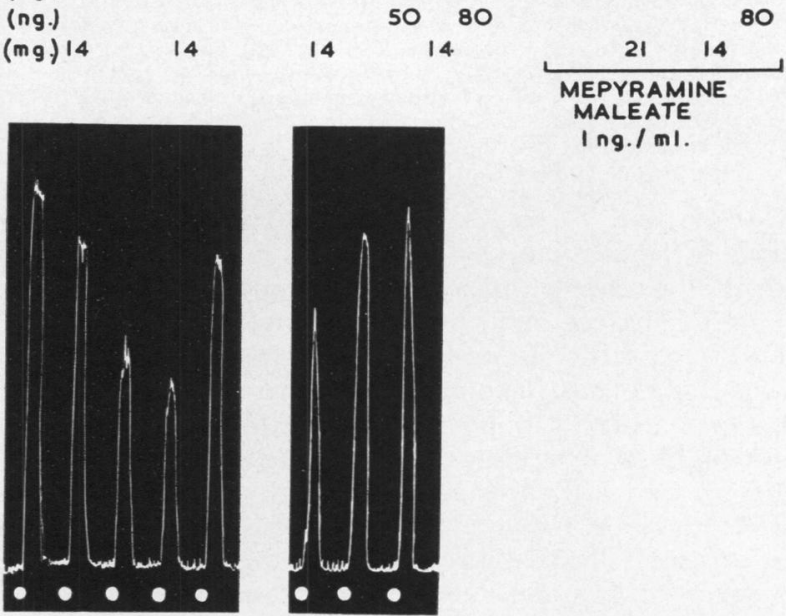

HISTAMINE (ng.)

30

20 ACETYLCHOLINE (ng.) COTTON DUST (mg.) 29 21

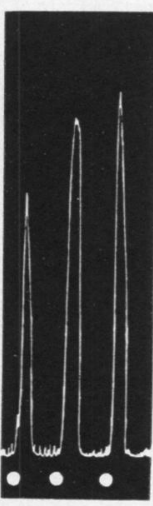

Ing. $/ \mathrm{ml}$ 


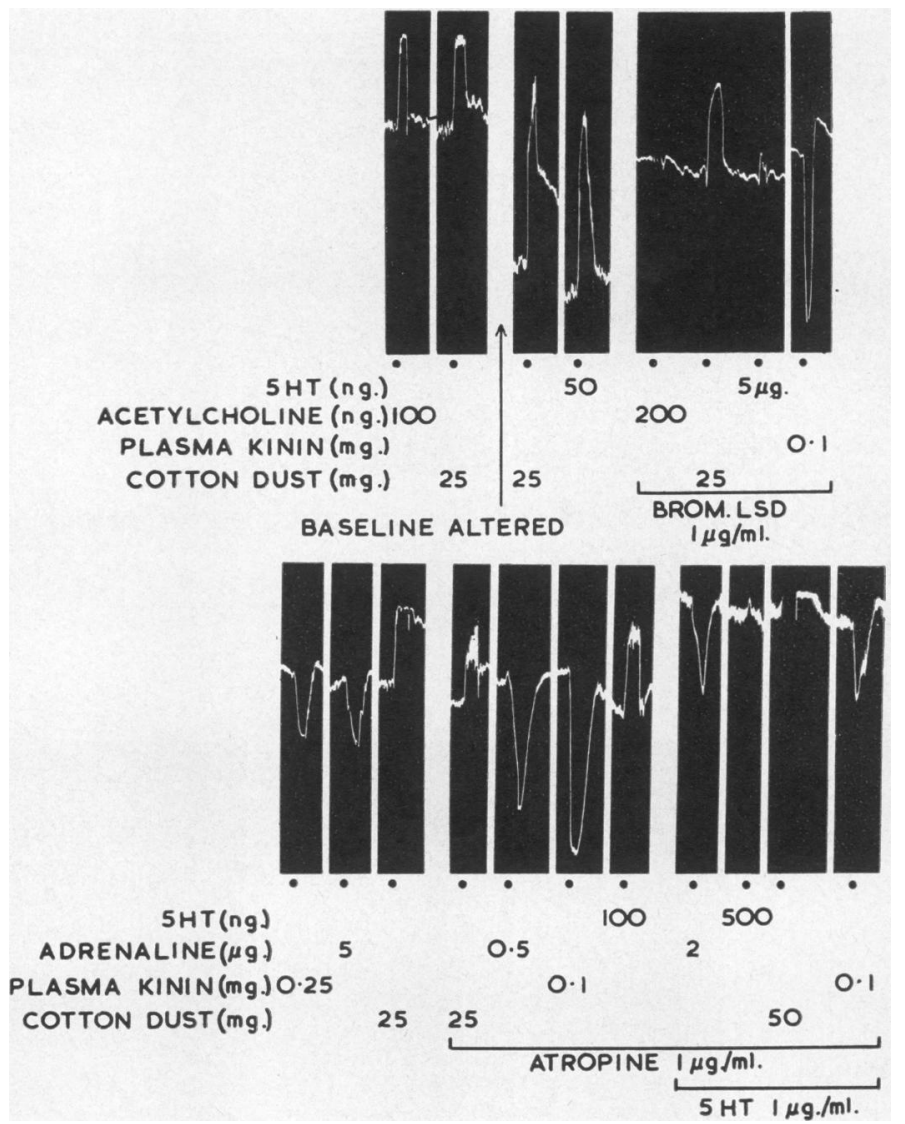

FIG. 10.-Rat duodenum. Upper tracings show contractions to 5-hydroxytryptamine (5-HT), acetylcholine, and cotton dust extract, with relaxations to plasma kinins. Brom-lysergic acid diethylamide $10^{-8}$, markedly antagonized 5-HT but had no effect on the other agonists. Lower tracings show an experiment in which first atropine $10^{-6}$ and then 5-hydroxytryptamine $10^{-6}$ and atropine $10^{-6}$ were added to the de Jalon's fluid. Cotton dust extract continued to contract the tissue under these conditions; small doses $(0 \cdot 1 \mathrm{mg}$.) plasma kinin always caused a relaxation.

trations of 5-hydroxytryptamine $\left(10^{-6}\right.$ and $10^{-4}$ ) in the bathing Ringer. Under these conditions of raised tone, the contractor activity was minimized and any relaxant activity due to the presence of a kinin would have shown itself more readily. The relaxations caused by both plasma kinin $(1.0 \mathrm{mg}$.) and adrenaline $(1 \mu \mathrm{g}$.) were increased more than five times by the presence of atropine. Plasma kinin and adrenaline relaxations were slightly greater with both atropine and 5-hydroxytryptamine in the Ringer, but the contractor responses to cotton dust extracts were increased.

Bradykinin is known to be inactivated by incubation with chymotrypsin (Rocha e Silva, Beraldo, and Rosenfeld, 1949; Hilton and Lewis, 1955), and wasp kinin by incubation with trypsin (Holdstock, Mathias, and Schachter, 1957). Samples of cotton dust extract were incubated with chymotrypsin (195 units) and trypsin (525 units) for one hour at $37^{\circ} \mathrm{C}$. The contractor activity on both the guinea-pig ileum and the guinea-pig trachea was unaltered by either of the enzymes. The activity of the cotton dust extracts was also unaffected by incubation with a strong solution of papain which had been activated by treatment with cysteine hydrcchloride.

Parallel tests were carried out with all three enzyme solutions to ensure that they possessed proteolytic activity. Thus there was both biological and enzymatic evidence that the smooth muscle contraction activity was not due to any of the known

agents, the possibility was tested that it might be due to the presence of an active polypeptide, such as a kinin. The rat duodenum preparation of Horton (1959) relaxes in response to kinins while contracting with doses of acetylcholine and 5-hydroxytryptamine. In such a preparation it was demonstrated that the cotton dust extracts contracted the muscle both before and after the addition of a plasma kinin which had a relaxant effect. Fig. 10 illustrates these effects and shows the resistance of the cotton dust extracts to brom-lysergic acid in a concentration of $10^{-6}$. Further experiments with the rat duodenum preparations have shown that cotton dust extracts were resistant to atropine $\left(10^{-6}\right)$ and that they continued to contract the tissue with high concen- active polypeptides.

The Action of Particulate Matter.-Several experiments were made, using the guinea-pig ileum, to test how far the stimulant activity was associated with the particulate material of the cotton extract. It was found that the deposit after centrifugation was always able to excite the ileum, and that this stimulant activity persisted after repeated washing with saline, centrifuging, and resuspension in saline. The response was always of short latency, so that it is unlikely that it was due to the release by the particles of a soluble material which was not extracted by previous washing for many hours.

Some simple experiments were made on the 
particles. Under the microscope most of them appeared to be about $1 \mu$ in diameter. When suspended in saline they took up methylene blue avidly, were flocculated with ferric chloride, and moved to the anode in an electrophoretic chamber. These results show that they are negatively charged.

\section{Possibility of Release of Active Substances by Cotton Dust Extracts}

Another possibility which had to be considered was that a substance might be released in the body by the cotton dust extracts and that this substance caused contraction of the pulmonary bronchioles. One of the known substances which had these properties was histamine and experiments on histamine release were carried out.

Rat Peritoneum.-The results of the histamine release experiments using this technique are given in Table 4. A little histamine was released by both saline and distilled water extracts of Dutch and English cotton dust whether freshly prepared or after storage at $-15^{\circ} \mathrm{C}$. The uncentrifuged extracts, which contained a considerable amount of particulate matter, liberated more histamine than the clear supernatants. However, extracts prepared from dust which had been washed with acetone had little or no histamine releasing properties. Acetone extracts of English cotton dust were therefore prepared and the amount of histamine released approximated to that released by the supernatants of the distilled water extract. An acetone extract of jute dust also liberated histamine. Although all these extracts released histamine in the rat, the amounts were very small when compared with the levels produced by the injection of a low concentration $\left(2 \times 10^{-6}\right)$ of compound $48 / 80$.
Perfused Cat Skin and Cat Blood Pressure.-This technique confirmed that no histamine was released by distilled water extracts prepared from acetonewashed cotton dust. Typical histamine responses of the cat's blood pressure were never obtained by injecting either English or Dutch distilled water extracts, or saline cotton dust extracts, or acetone extracts of English or jute dusts, even when large doses were given. The blood pressure response was a rapid depressor followed by a pressor effect which was similar with all the extracts when tested on several cats.

Experiments with Blood-bathed Organs and on Bronchoconstriction.-Experiments with the bloodbathed organ technique (Vane, 1958) using three tissues, guinea-pig ileum, rat stomach, and rat duodenum, confirmed the result that no histamine was released in the cat. But the injection both of English and of Dutch cotton dust extracts caused the slow release of some other substance which contracted the guinea-pig ileum, relaxed the rat duodenum, and had no effect on the rat stomach strip. It has been shown, earlier, that the extract does not, in vitro, relax the rat duodenum even when its tone is increased. The relaxation of the bloodbathed rat duodenum is due, therefore, to the release of a substance with the properties of a kinin. Incubation of $0.5 \mathrm{ml}$. of the centrifuged extract with $5 \mathrm{ml}$. cat's blood for six minutes did not alter the effect of the extract when the mixture was injected. However, when the uncentrifuged extract was similarly incubated and the mixture injected, the effects on the guinea-pig ileum and rat duodenum were much greater. The responses were much more pronounced with injections into the blood on its passage from the cat's carotid artery to the tissues, than with intravenous injections. This might be

TABLE 4

HISTAMINE RELEASE IN RAT PERITONEUM

\begin{tabular}{|c|c|c|}
\hline Material Injected & $\begin{array}{l}\text { Dose in Dust Equivalents } \\
\text { (All Doses Given in } 20 \mathrm{ml} \text {. Krebs) }\end{array}$ & $\begin{array}{l}\text { Histamine Concentrations/ml. Fluid } \\
\text { Obtained (Values Corrected for } \\
\text { Dust Extract Activity) }\end{array}$ \\
\hline $\begin{array}{l}\text { English Cotton Dust Extracts: } \\
\text { Whole freshly prepared saline extract } \\
\text { After storage at }-15^{\circ} \mathrm{C} .(1) \\
\text { Supernatant from (1) } \\
\text { Distilled water extract (supernatant) } \\
\text { Distilled water extract of acetone washed dust } \\
\text { Acetone extract }\end{array}$ & $\begin{array}{l}300 \mathrm{mg} . \\
300 \mathrm{mg} . \\
300 \mathrm{mg} . \\
250 \mathrm{mg} . \\
358 \mathrm{mg} . \\
1,430 \mathrm{mg} . \\
300 \mathrm{mg} .\end{array}$ & $\begin{array}{l}115 \mathrm{ng} . \\
160 \mathrm{ng} . \\
35 \mathrm{ng} . \\
45 \mathrm{ng} . \\
\text { Nil. } \\
\text { Trace } \\
35 \mathrm{ng} .\end{array}$ \\
\hline $\begin{array}{l}\text { Dutch Cotton Dust Extracts: } \\
\text { Whole freshly prepared saline extract } \\
\text { After storage at }-15^{\circ} \mathrm{C} \text {. } \\
\text { Jute dust-acetone extract } \\
\text { Histamine liberator: }\end{array}$ & $\begin{array}{l}300 \mathrm{mg} . \\
300 \mathrm{mg} . \\
300 \mathrm{mg} . \\
40 \mathrm{\mu g} . \\
\left(2 \times 10^{-6}\right)\end{array}$ & $\begin{array}{l}35 \mathrm{ng} . \\
12 \mathrm{ng} . \\
55 \mathrm{ng} . \\
300 \mathrm{ng} .\end{array}$ \\
\hline (Compound 48/80) & $\begin{array}{r}200 \mu \mathrm{g} \\
\left(10^{-5}\right)\end{array}$ & $1,500 \mathrm{ng}$. \\
\hline
\end{tabular}




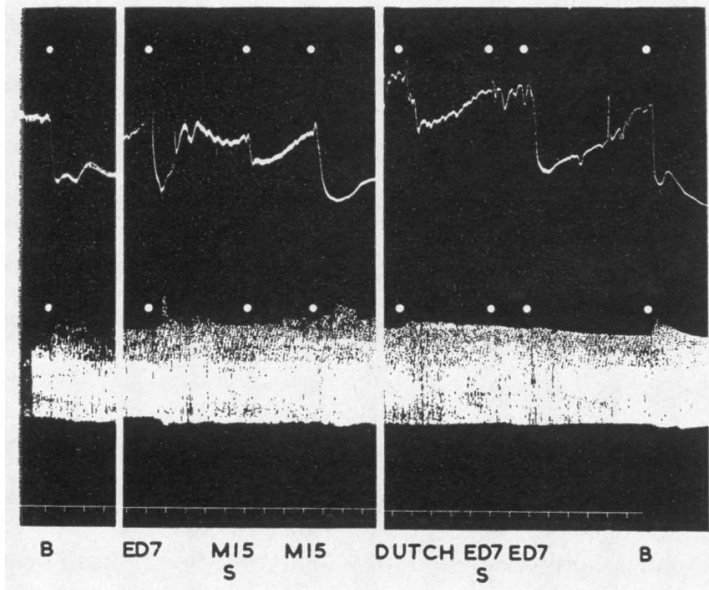

FIG. 11--Guinea-pig under urethane; record of blood pressure (upper tracing) bronchial tone by Konzett method (middle tracing) and time in minutes. Intravenous injections. The response to bradykinin (B: $0.5 \mathrm{mg}$. of an impure preparation) by the bronchi diminishes during the experiment.

Three dust extracts (ED7, M15, and Dutch) produce bronchoconstriction and fall in blood pressure. The bronchial effect diminishes on repetition (compare the two responses to ED7); and the supernatant (5) of M15 and ED7 is virtually inactive on the bronchi.

The latency of response to the injections, marked by white dots, is longer with the extracts than with bradykinin.

taken to suggest release primarily in the isolated tissues, but it seems more probable that the release took place in the blood itself. When injections are given into the arterial circuit, the concentration of the products of reaction between blood and the dust extract when they reach the assay tissue would be relatively much higher than if the extracts are given intravenously and the reaction products thus diluted in the circulation.

Further evidence for the release of an active substance in the whole animal was obtained from experiments on guinea-pigs using the Konzett apparatus (Konzett and Rössler, 1940) for measuring bronchoconstriction (Fig. 11). Intravenous injection of dust extracts caused a delayed bronchoconstrictor response which was of slower onset than the response to either histamine or bradykinin. It was associated with a fall in arterial blood pressure, which resembled that due to bradykinin; histamine caused a rise in blood pressure, sometimes preceded by a brief fall. Further, the response diminished with successive doses of dust extract as though some store was being depleted and no more bronchoconstrictor could be released. In agreement with the experiments in cats, the extracts containing particles were found to possess considerably more activity than those which had been centrifuged. A large dose of 48/80 (100 $\mu \mathrm{g} . / \mathrm{kg}$.), failed to produce any bronchoconstriction and failed to reproduce the fall in blood pressure seen with dust extracts.

Comparison with Dutch Dust.-The contractor activity in the Dutch cotton dust extracts was apparently of the same type as in the English cotton dusts. It was not diminished on storing the extracts at $-15^{\circ} \mathrm{C}$. and was not antagonized either by mepyramine $\left(2 \times 10^{-8}\right)$ or by hyoscine $\left(10^{-8}\right)$. The extracts released histamine in the rat peritoneum, although less was released by extracts which had been stored at $-15^{\circ} \mathrm{C}$., but neither fresh nor stored extracts liberated histamine in the whole cat. When the activity of Dutch dust extracts was compared with those of the English dust extracts on the same piece of ileum, the potency was slightly less than that of $M$ dust and slightly more than $E$ dust. Dutch dust extracts also produced the same effects as those prepared from English dusts in the bloodbathed organ and Konzett experiments; thus both the contractor and releasing properties were similar.

\section{Pyrogens}

A typical pyrogenic response was obtained to $0.001 \mathrm{ml}$. cotton dust extract (equivalent to $0.1 \mathrm{mg}$. dust) when tested on two Himalayan rabbits using the standard thermocouple method for measuring rectal temperatures. However, when rabbits were exposed to an atmosphere of cotton dust in a mill no pyrogenic effect was observed. Pyrogens in very large doses (60 to $100 \mu \mathrm{g}$., where a fraction of a microgram is pyrogenic) had smooth muscle contractor activity when tested on the guinea-pig ileum and rat stomach strip, but tachyphylaxis occurred on both preparations. Fig. 12 illustrates an experiment on the rat stomach strip, in which $80 \mu \mathrm{g}$. "piromen" was first equivalent to $1 \mathrm{ng}$. HT, but the response diminished with successive doses while the response to $1 \mathrm{ng}$. HT remained unchanged.

\section{DISCUSSION}

The chemical and biological results both indicate the presence of a number of biologically active substances in extracts made from the dust collected in the card-rooms of several cotton mills. Two known smooth-muscle contractor substances, histamine and 5-HT, were found to be present, together with an unknown contractor. The histamine content varied considerably from one sample of dust to another, from trivial amounts to possibly significant quantities; but the concentrations of 5-HT and the unknown contractor were relatively constant in dusts collected from the same mill, although they varied slightly from one mill to another. There was also good evidence that the cotton dust contained a 
Fig. 12.-Rat stomach strip. Agonists were 5-hydroxytryptamine and "piromen" a solution of pseudomonas polysaccharide containing $400 \mu \mathrm{g} . / \mathrm{ml} . ; 1 \mu \mathrm{g} . / \mathrm{kg}$. of this solution is sufficient to cause pyrogenic response in rabbits. Tissue exhibited tachyphylaxis after several doses of "piromen."

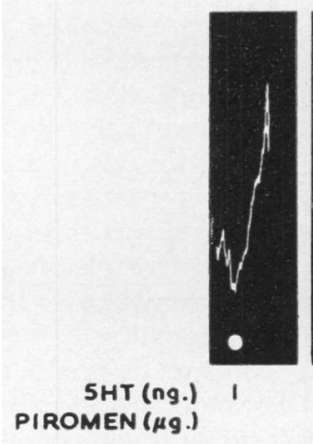

substance which will release a bronchoconstrictor when injected into a whole animal.

The clinical picture of byssinosis and experiments carried out in cotton mills suggest that inhalation of the dust causes a delayed bronchoconstriction which lasts for several hours as well as a more rapid fall in ventilatory capacity. The small amounts of 5-HT, the unknown smooth muscle contractor, and histamine, when it is present, could perhaps be responsible for the relatively rapid fall in M.B.C. recorded by McKerrow et al. (1958) with both byssinotic and non-byssinotic subjects; but this may or may not be the factor causing the disease. The hypothesis that a kinin-like substance is being released by the dust is more consistent with some typical features of byssinosis: the slow onset of the symptoms throughout the day, the fact that byssinotics still experience considerable respiratory discomfort in the evening after leaving the mill atmosphere, and the lack of pathological lesions observable in chest radiographs or at necropsy. The release of an active substance is also consistent with the observation that byssinotics appear to be worse on a Monday and that their symptoms wear off during the week. The precursor of the bronchoconstrictor in the blood stream or tissues would perhaps become relatively depleted during the week and then be built up again at the week-end when the subjects were not exposed to the cotton dust. Prausnitz (1936) suggests that there may be an accommodation of the cotton workers to the atmosphere in the mill and that they breathe less deeply as they become used to the atmosphere, but this does not seem altogether likely, as this picture is not seen in other dusty industries such as coalmining where the industry is not concerned with vegetable fibres. Both the smooth muscle contractor activity and the releaser activity are soluble in saline and distilled water and could presumably penetrate into the blood stream through the bronchiole walls, but it is also possible that they could act locally; thus, there would be no systemic release of a kinin
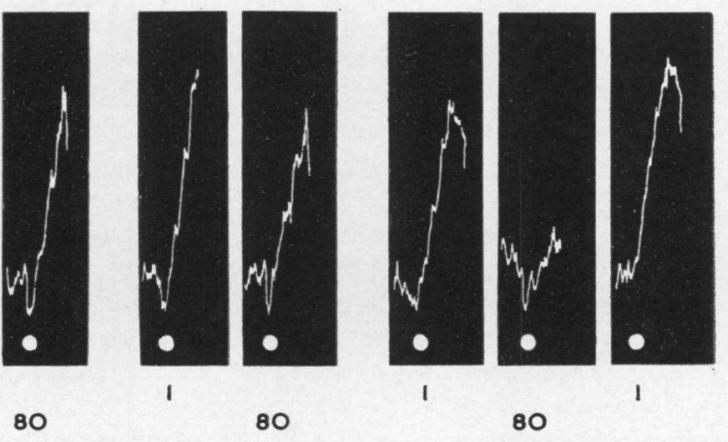

and only the bronchoconstrictor effects would be seen.

We have considered three other possible mec hanisms. First, cotton dust also contains pyrogenic substances and although no pyrogenic responses could be detected in rabbits exposed to cotton mill dust, very small doses of the dust extracts elicited typical pyrogenic responses. On the other hand, when mill workers first start in the mills they often experience a slight fever but this only lasts for a few days, and they do not usually have another attack. This so-called "Mill fever" has often been confused with byssinosis, but the general picture is not at all the same. It was necessary, however, to test whether the pyrogens in the dust might be responsible for the bronchoconstriction. It was found that extremely high doses of pure pyrogens only elicited small responses on preparations of smooth muscle and they rapidly exhibited tachyphylaxis, a picture quite unlike that shown by cotton dust extracts. There is little doubt that the pyrogens were responsible for the general feeling of malaise and sometimes the slight fever experienced by the subjects of the human experiments to be reported (McKerrow et al., 1958), but it seems unlikely that they could have caused the respiratory changes.

Secondly, in this study, cotton dust extracts have been found to contain materials of a proteinous nature which are presumably derived from the cotton plant; and it might be thought that these would produce a type of sensitization reaction. Previous workers (Prausnitz, 1936; Cayton, Furness, Jackson; and Maitland, 1952) have carried out a number of skin test experiments which have produced conflicting results. From these it appears that cotton dust extracts can produce both an "early" and a "late" reaction, the former being due, perhaps, to the histamine and HT in the dust, and the latter being due, perhaps, to the unknown substance or substances; but Cayton et al. (1952) concluded from their skin tests that there was no specific hypersensitivity peculiar to byssinosis. Epidemiological surveys 
among cotton workers and experiments with normals exposed to mill dust for the first time showed that most subjects experienced an early fall in M.B.C. and some of them a pyrogenic response. Moreover, there does not appear to be any evidence suggesting that those workers who develop byssinosis are also prone to allergies such as hay fever. There appears to be no reason, at present, for including a sensitization mechanism in the aetiology of byssinosis.

Thirdly, experiments were made on the histaminereleasing power of cotton dust extracts. We could not, however, obtain evidence to support the hypothesis of Bouhuys et al. (1960) that some of the symptoms of byssinosis are caused by direct histamine release (not involving an antigen-antibody reaction). Extracts prepared from both English and Dutch cotton dust failed to produce histamine release in cat tissues; by the very sensitive method of intraperitoneal injection into the rat, a small quantity was released, but it was unimpressive when compared with the amount released by a low dose of compound $48 / 80$. The actions of the extracts in the guinea-pig did not resemble those of histamine nor of histamine-release. It is possible that the extracts used in Holland were not exactly the same as those used by us, although the dust samples were similar and the method of preparation was the same. Antweiler (1960) has also furnished evidence that cotton dust extracts can release histamine, using larger doses. It is interesting that, although he observed effects on the cat's blood pressure which we have not seen, his estimate of the potency of cotton dust in releasing histamine compared to that of $48 / 80$ is that the extract from $200 \mathrm{mg}$. of dust is equivalent to $25 \mu \mathrm{g}$. $48 / 80$; this is quite close to our estimate based on rat experiments (Table 4), giving a potency ratio of the order of 10,000. Bearing in mind that the non-antigenic histamine-releasing agents are rather inactive in producing bronchospasm, that other signs of histamine-release are not seen in byssinosis, and that an antihistamine does not relieve the symptoms of byssinosis when given to cotton workers, we have concluded that this action can hardly be supposed to contribute to the clinical picture. The nature of the histamine-releasing factor is obscure, although our finding that it can be extracted with acetone suggests that it is a fatty, perhaps somewhat surfaceactive, material. Histamine-releasing activity and surface-activity are sometimes associated (Paton, 1957b).

There is a considerable risk in relating the features of clinical byssinosis to the results of experiments of the type discussed here, for there is considerable doubt as to the "dose" of dust received by cotton workers; the dose is spread out in time, whereas in the experimental work it is applied in a single administration; and we have almost no basis for comparing the characteristics of the intrabronchial with, for instance, the intravenous route, for so heterogeneous a material as cotton dust. The activities so far found, however, do suggest that pharmacologically active materials in the dust may be responsible for the disease, and that their elimination might relieve it. Further, if one compares the conclusion by Roach and Schilling that, clinically, byssinosis is associated with dust particles of medium size, and the conclusion by McKerrow et al. (1958) that in short-term studies the ventilatory changes could well be due to the fine particles alone, it seems possible that the apparent contradiction may be resolved pharmacologically; such a result could be obtained if the factors acting directly on smooth muscle were associated with fine particles (coming into solution with a corresponding rapidity), and the factors releasing a bronchoconstrictor substance accompanied the medium-sized particles (dissolving more slowly).

We are much indebted to Mr. D. A. Green and his staff for technical assistance, to Dr. A. Bouhuys for supplies of dust from a Dutch mill; and to Dr. J. R. Vane, Dr. R. S. F. Schilling, and Mr. S. A. Roach for helpful discussion.

\section{REFERENCES}

Antweiler, H. (1960). Arch. Gewerbepath. Gewerbehyg., 17, 574. Ashwell, G. (1957). Methods in Enzymology, ed. S. P. Colowick and N. O. Kaplan, Vol. 3, pp. 84 and 85. Academic Press, New York.

Bouhuys, A., Lindell, S.-E., and Lundin, G. (1960). Brit. med. J., 1, 324

Cayton, H. R., Furness, G., Jackson, D. S., and Maitland, H. B. (1952) Brit J industr. Med 9 ,

Fawcett, D. W. (1954). J. exp. Med., 100, 217.

Feldberg, W., and Paton, W. D. M. (1951). J. Physiol. (Lond.), 114, 490

Haworth, E., and Macdonald, A. D. (1937). J. Hyg. (Lond.), 37, 234. Hilton, S. M., and Lewis, G. P. (1955). J. Physiol. (Lond.), 129, 253. Holdstock, D. J., Mathias, A. P., and Schachter, M. (1957). Brit. J. Pharmacol., 12, 149.

Horton, E. W. (1959). ibid., 14, 125.

Konzett, H., and Rössler, R. (1940). Arch. exp. Path. Pharmak., 195,71 .

Macdonald, A. D., and Prausnitz, C. (1936). Spec. Rep. Ser. med.

MeKerrow, Coun. (Lond.), No. 212, p. 26. McDermott, M., Gilson, J. C., and Schilling, R. S. F. (1958). Brit. J. industr. Med., 15, 75.

Maitland, H. B., Heap, H., and Macdonald, A. D. (1932). Report of the Departmental Committee on Dust in Card Rooms in the Cotton Industry, Appendix VI. [Home Office.] H.M.S.O., London.

Paton, W. D. M. (1957a). J. Physiol. (Lond.), 137, 35P.

Pat (1957b). Pharmacol. Rev., 9, 269.

Prausnitz, C. (1936). Spec. Rep. Ser. med. Res. Coun. (Lond.), No.

Roach, S. A., and Schilling, R. S. F. (1960). Brit. J. industr. Med. 17,1 .

Rocha e Silva, M., Beraldo, W. T., and Rosenfeld, G. (1949). Amer. . Physiol., 156, 261.

Rodnight, R. (1956). Biochem. J., 64, 621.

Rydon, H. N., and Smith, P. W. G. (1952). Nature (Lond.), 169, 922.

Rydon, H. N., and Smith, P. W. G. (1952). Nath

Schilling, R.S. F. (1956). Lancet, 2, 261, 319.

Vane, J. R. (1957). Brit. J. Pharmacol., 12, 